\title{
Pengaruh Kepuasan Kerja dan Motivasi Terhadap Peningkatan Produktivitas Pegawai di PT. Glory Anugrah Tour
}

\section{Effect of Job Satisfaction and Motivation on Improvement Employee Productivity at PT. Glory Anugrah Tour}

\author{
Tri Susilowati ${ }^{1}$, Lilik Suryaningsih ${ }^{2}$, SusiArijanti $^{3}$ \\ 1,2,3 Sekolah Tinggi Penerbangan Aviasi, Jakarta, Indonesia, \\ *Penulis koresponden : trisusilowati.syg77@gmail.com
}

\begin{abstract}
ARTICLE INFO
PBJ use only:

Received date 10 September 2020

Revised date 7 Oktober 2020

Accepted date 21 Oktober 2020
\end{abstract}

\begin{abstract}
This study aims to determine the indicators of management success seen from competent resources in increasing employee productivity at PT. Glory Anugrah Tour with human resources as capital and technology occupies a very strategic position in realizing the availability of goods and services. Many people have abandoned the use of human resources, capital and technology extensively. On the contrary, the pattern is shifting towards more intensive use of all economic resources. Economic resources that are driven effectively require organizational and technical skills so that they have a high level of yield, meaning that the results obtained are balanced with the input processed. Through various improvements in working methods, waste of time, energy and various other inputs will be reduced as far as possible. The results will certainly be better and many things can be saved. What is clear, time is not wasted, energy is deployed effectively and the achievement of business goals can be well organized, effective and efficient. Low productivity is often associated with education levels. It is assumed that the higher a person's level of education, the higher the level of productivity he may be able to achieve, because this may be seen from the ability to read and write one of the important elements of the early stages of the industrialization program. At a higher level of industrialization, more advanced technical skills are required.
\end{abstract}

Keywords : Job Satisfaction; Motivation; Productivity. 


\begin{abstract}
ABSTRAK
Penelitian ini bertujuan untuk mengetahui indikator keberhasilan manajemen dilihat dari sumber daya yang berkompeten dalam peningkatan produktivitas pegawai di PT. Glory Anugrah Tour dengan sumber daya manusia sebagai modal dan teknologi menempati posisi yang amat strategis dalam mewujudkan tersedianya barang dan jasa. Penggunaan sumber daya manusia, modal dan teknologi secara ekstensif telah banyak ditinggalkan orang. Sebaliknya, pola itu bergeser menuju penggunaan secara lebih intensif dari semua sumbersumber ekonomi. Sumber-sumber ekonomi yang digerakkan secara efektif memerlukan keterampilan organisatoris dan teknis sehingga mempunyai tingkat hasil guna yang tinggi, artinya hasil yang diperoleh seimbang dengan masukan yang diolah. Melalui berbagai perbaikan cara kerja, pemborosan waktu, tenaga dan berbagai input lainnya akan bisa dikurangi sejauh mungkin. Hasilnya tentu akan lebih baik dan banyak hal yang bisa dihemat. Yang jelas, waktu tak terbuang sia-sia, tenaga dikerahkan secara efektif dan pencapaian tujuan usaha bisa terselenggara dengan baik, efektif dan efisien. Rendahnya produktivitas sering kali dikaitkan dengan tingkat pendidikan. Diasumsikan makin tinggi tingkat pendidikan seseorang, makin tinggi pula tingkat produktivitas yang mungkin dapat dicapainya, karena ini barangkali, dilihat dari kemampuan membaca dan menulis merupakan salah satu elemen penting tahap-tahap awal program industrialisasi. Pada tingkat industrialisasi yang lebih tinggi dibutuhkan ketrampilan teknis yang lebih maju.
\end{abstract}

Kata kunci : Optimalisasi; Konektivitas; Pesawat Perintis; Tol Laut; Logistik

\title{
A. PENDAHULUAN
}

Perkembangan industri jasa penerbangan di Indonesia, khususnya untuk penerbangan komersial berjadwal semakin marak, sejak dikeluarkannya deregulasi yang mengatur transportasi udara pada tahun 1999, berupa serangkaian paket deregulasi, salah satunya adalah Keputusan Menteri Perhubungan Nomor 81 Tahun 2004 tentang Pendirian Perusahaan penerbangan di Indonesia. Banyaknya jumlah maskapai penerbangan yang beroperasi di Indonesia secara langsung menciptakan persaingan yang cukup ketat. Walaupun menghadapi tekanan dengan meningkatnya harga bahan bakar, industri penerbangan nasional tetap mengalami pertumbuhan yang pesat.

Berikut data jumlah maskapai penerbangan yang beroperasi di Indonesia

\begin{tabular}{|c|l|l|}
\hline No. & \multicolumn{1}{|c|}{$\begin{array}{c}\text { Maskapai Penerbangan } \\
\text { Domestik }\end{array}$} & \multicolumn{1}{|c|}{$\begin{array}{c}\text { Maskapai Penerbangan } \\
\text { Internasional }\end{array}$} \\
\hline 1. & Garuda Indonesia & Korean Airlines \\
\hline 2. & Citilink Airlines & China Airlines \\
\hline 3. & Batik Airlines & Singapore Airlines \\
\hline 4. & Wings Airlines & Japan Airlines \\
\hline 5. & Lion Air & Cathay Pacipic \\
\hline
\end{tabular}

Data: Situs Departemen Perhubungan udara tahun 2019 
Pengukuran produktivitas merupakan suatu alat manajemen yang penting disemua tingkatan ekonomi. Dibeberapa Negara maupun perusahaan pada akhir-akhir ini telah terjadi kenaikan minat pada pengukuran produktivitas. Pada saat kita membicarakan alasan mengapa kita harus mengukur produktivitas. Pada tingkat sektoral dan nasional, produktivitas menunjukkan kegunaannya dalam membantu evaluasi penampilan, perencanaan, kebijakan pendapatan, upah dan harga melalui identifikasi faktor-faktor yang mempengaruhi distribusi pendapatan, membandingkan sektor-sektor ekonomi yang berbeda untuk menentukan prioritas kebijakan bantuan, menentukan tingkat pertumbuhan suatu sektor atau ekonomi, mengetahui pengaruh perdagangan internasional terhadap perkembangan ekonomi dan seterusnya. Pada tingkat perusahaan, pengukuran produktivitas terutama digunakan sebagai sarana manajemen untuk menganalisa dan mendorong efisiensi produksi. Pertama, dengan pemberitahuan awal, instalasi dan pelaksanaan suatu sistem pengukuran, akan meninggikan kesadaran pegawai dan minatnya pada tingkat dan rangkaian produktivitas. Kedua, diskusi tentang gambarangambaran yang berasal dari metode-metode yang relatif kasar ataupun dari data yang kurang memenuhi syarat sekalipun, ternyata memberi dasar bagi penganalisaan proses yang konstruktif atas produktif. Manfaat lain yang diperoleh dari pengukuran produktivitas mungkin terlihat pada penempatan perusahaan yang tetap seperti dalam menentukan target/sasaran tujuan yang nyata dan pertukaran informasi antara tenaga kerja dan manajemen secara periodik terhadap masalah-masalah yang saling berkaitan. Pengamatan atas perubahanperubahan dari gambaran data yang diperoleh sering nilai diagnostik yang menunjuk pada kemacetan dan rintangan dalam meningkatkan penampilan oraganisasi. Satu keuntungan dari pengukuran produktivitas adalah pembayaran staf. Gambaran data melengkapi suatu dasar untuk manfaat atas penampilan yang ditingkatkan.

Perkembangan jasa pelayanan maskapai penerbangan dari tahun ke tahun semakin menjadi perhatian masyarakat luas. Hal itu dapat dilihat dari ketatnya persaingan pelayanan, harga dan promosi yang ditawarkan berbagai maskapai penerbangan. Daya tarik (attractiviness) industri penerbangan cukup besar dan menjanjikan. Hal ini dapat dilihat banyaknya industri penerbangan yang menggeluti bisnis tersebut, begitu juga dengan Maskapai Low Cost Carrier (LCC) yang memangkas meniadakan fasilitas premium, maskapai nasional dan domestik yang mencoba mempertahankan tarif dengan menyesuaikan kualitas pelayanan maksimal dari Maskapai Low Cost Carrier (LCC) yang sudah memang 
diakui oleh seluruh pengguna fasilitas jasa penerbangan khususnya kalangan backpacker atau menengah ke bawah.

Setiap perusahaan, baik yang bergerak di bidang jasa maupun non-jasa, dalam melakukan kegiatan bisnis memerlukan strategi yang mampu menempatkan perusahaan pada posisi yang terbaik, mampu bersaing serta terus berkembang dengan mengoptimalkan semua potensi sumber daya yang dimiliki. Perusahaan jasa memiliki karakteristik yang berbeda dengan perusahaan non-jasa. Pemasaran jasa penerbangan merupakan suatu proses penyesuaian antara permintaan penumpang pada saat ini, permintaan potensial, permintaan masa depan, dan penawaran dari suatu maskapai penerbangan.

Produktivitas kerja karyawan pada PT. Glory Anugrah Tour merupakan suatu akibat dari persyaratan kerja yang harus dipenuhi oleh setiap karyawan yang bekerja di industri penerbangan. Persyaratan itu adalah kesediaan karyawan untuk bekerja dengan penuh semangat dan tanggung jawab. Seorang karyawan yang memenuhi prasyarat kerja adalah karyawan yang dianggap mempunyai kemampuan, jasmani yang sehat, kecerdasan, dan pendidikan tertentu dan telah memperoleh keterampilan untuk melaksanakan tugas yang bersangkutan dan memenuhi syarat yang memuaskan dari segi kualitas dan kuantitas. Motivasi dan pengalaman kerja yang baik dapat juga menunjang keberhasilan suatu perusahaan dalam mencapai tujuannya. Sebab melalui adanya dua faktor tersebut akan menciptakan tingkat produktivitas kerja yang tinggi sehingga menunjang keberhasilan perusahaan. Sebaliknya jika tingkat produktivitas kerja menurun akan menghambat perusahaan tersebut dalam mencapai tujuannya. Setiap perusahaan selalu menginginkan produktivitas dari setiap karyawannya meningkat. Untuk mencapai hal tersebut, perusahaan harus memberikan motivasi yang baik kepada seluruh karyawannya agar dapat mencapai prestasi kerja dan meningkatkan produktivitas. Selain itu ditambah suatu pengalaman kerja yang dimiliki oleh para karyawannya, akan memberikan suatu pengaruh yang besar dalam upaya mencapai tingkat produktivitas yang tinggi.

Konsep produktivitas kerja dapat dilihat dari dua dimensi, yaitu dimensi individu dan dimensi organisasian. Dimensi individu melihat produktivitas dalam kaitannya dengan karakteristik-karakteristik kepribadian individu yang muncul dalam bentuk sikap mental dan mengandung makna keinginan dan upaya individu yang selalu berusaha untuk meningkatkan kualitas kehidupannya. Sedangkan dimensi keorganisasian melihat produktivitas dalam kerangka hubungan teknis antara masukan (input) dan keluaran (output). Oleh karena itu 
dalam pandangan ini, terjadinya peningkatan produktivitas tidak hanya dilihat dari aspek kuantitas, tetapi juga dapat dilihat dari aspek kualitas.

Sumber daya manusia memegang peranan penting dalam setiap penyelenggaraan kegiatan perusahaan meskipun peran dan fungsi dari tenaga kerja telah banyak digantikan dengan mesin-mesin industri. Tetapi pada kenyataannya sampai saat ini tenaga kerja masih menjadi faktor yang penting dalam menentukan jalannya proses produksi. Maka dari itu setiap perusahaan menghendaki agar setiap tenaga kerja dapat bekerja secara efektif dan efisien. Rendahnya kualitas tenaga kerja sangat berpengaruh terhadap pengembangan dan peningkatan produksi dalam berbagai bidang. Hal tersebut dikarenakan tenaga kerja memegang peranan penting dalam usaha untuk mencapai tujuan perusahaan. Suatu perusahaan yang mempunyai tujuan untuk mengembangkan usahanya, mempertahankan hidup, dan menghasilkan laba, maka produktivitas kerja karyawan sangat penting sebagai alat ukur keberhasilan dalam menjalankan usaha. Keberhasilan suatu perusahaan tercermin dari hasil kerja masing-masing individu dalam perusahaan, hasil kerja tersebut akan berpengaruh pada produktivitas organisasi secara keseluruhan.

Semakin meningkatnya produktivitas kerja karyawan diharapkan dapat berdampak pada peningkatan kesejahteraan karyawan pada perusahaan tersebut. Kenaikan produktivitas tenaga kerja akan memberikan manfaat yang besar bagi tenaga kerja, dunia usaha maupun pemerintah. Dari sisi tenaga kerja produktivitas yang tinggi akan menambah jumlah upah yang diterima, bagi dunia usaha produktivitas tenaga kerja memberikan manfaat untuk menjaga kelangsungan hidup perusahaan dan bagi pemerintah dapat menaikkan pendapatan nasional. Produktivitas kerja karyawan merupakan suatu akibat dari persyaratan kerja yang harus dipenuhi oleh setiap karyawan. Persyaratan itu adalah kesediaan karyawan untuk bekerja dengan penuh semangat dan tanggung jawab. Seorang karyawan yang memenuhi prasyarat kerja adalah karyawan yang dianggap mempunyai kemampuan, jasmani yang sehat, kecerdasan, dan pendidikan tertentu dan telah memperoleh ketrampilan untuk melaksanakan tugas yang bersangkutan dan memenuhi syarat yang memuaskan dari segi kualitas dan kuantitas. 


\section{B. LANDASAN TEORI}

\section{Pengertian Kepuasan Kerja}

Essensi dalam pandangan Islam kepuasan kerja itu terjadi apabila suatu pekerjaan yang dilakukan dapat membantu orang lain dalam meringankan pekerjaannya, karena"sebaikbaiknya manusia adalah yang berguna bagi orang lain”. Dalam buku (Indrasari:2008) Faktor-faktor yang mempengaruhi kepuasan kerja adalah:

a. Kondisi kerja, artinya jika seluruh kebutuhan seseorang untuk bekerja terpenuhi baik itu dari bahan yang dibutuhkan ataupun dari lingkungan yang menunjang maka kepuasan kerja akan terjadi.

b. Peraturan, budaya serta karakteristik yang ada dalam organisasi tersebut, yang jika peraturan dalam menjalankan pekerjaannya dapat mendukung terhadap pekerjaannya maka karyawan atau para pekerja akan merasakan kepuasan kerja dan kompensasi dari pekerjaannya yang seimbang dengan pekerjaan yang telah dilakukan.

c. Efisiensi kerja, dalam hal ini dikaitkan dengan kemampuan seseorang dalam pekerjaan, sehingga apabila kepuasan kerja itu ada salah satunya dengan bekerja sesuai dengan kemampuan masing-masing.

d. Peluang promosi, yaitu di mana adanya suatu peluang untuk mendapatkan penghargaan atas prestasi kerja seseorang diberikan jabatan dan tugas yang lebih tinggi dan disertai dengan kenaikan gaji. Promosi ini sangat mempengaruhi kepuasan kerja dapat dihargai dengan dinaikan posisinya disertai gaji yang akan diterimanya.

e. Rekan kerja atau partner kerja, kepuasan kerja akan muncul apabila dalam suatu organisasi terdapat hubungan yang baik. Misalnya anggota kerja mempunyai cara atau sudut pandang atau kebiasaan yang sama dalam melakukan suatu pekerjaan sehingga dalam bekerja juga tidak ada hambatan karena terjalin hubungan yang baik.

Organisasi dalam sistem sosial membutuhkan beberapa pertimbangan, yaitu keuntungan yang akan diberikan kepada organisasi dan yang diterima oleh anggotanya. Kepuasan merupakan ungkapan suatu pengakuan sebagai anggota organisasi sama bentuknya dan mengacu pada hal-hal yang dapat memuaskan organisasi (Armstrong: 2001). Artinya, anggota organisasi yang mempunyai orientasi afektif positif adalah anggota yang merasa puas, sedangkan mereka yang mempunyai orientasi afektif negatif 
adalah anggota yang tidak merasa puas. Kepuasan dalam pengertian organisasi sering dibedakan dengan kepuasan umum (general), karena kepuasan yang bersifat umum tidak mempunyai sistem sosial sebagai unit analisisnya (Armstrong: 2003).

Menurut (Umar:1999), dari hasil penelitian mereka menunjukkan, bahwa pengaruh dimensi inti kepuasan kerja sangat kuat untuk pekerja yang menginginkan tanggung jawab, makna pekerjaannya, pengendalian diri, umpan balik pelaksanaan kerja serta kesempatan untuk maju. Selanjutnya mereka mengemukakan juga, bahwa umumnya kepentingan seseorang terhadap kebutuhan relatif naik-turun sepanjang waktu, namun bila kepuasan itu dilihat dari hasil penelitian terhadap sikap kerja umumnya telah mencerminkan perhatian yang lebih besar terhadap efektivitas organisasi ketimbang kesejahteraan anggota. Dengan demikian, pengaruh dimensi inti kepuasan kerja sangat ditentukan oleh pekerja itu sendiri dengan keinginan untuk bertanggung jawab, memaknai pekerjaan, mengendalikan diri, memperoleh umpan balik pelaksanaan kerja serta kesempatan untuk maju dan kemudian kebutuhan itu relatif naik-turun sepanjang waktu, dan kepusan itu sering diperlihatkan dalam bentuk sikap kerja dengan efektivitas kerja tinggi.

Berdasarkan uraian di atas, penting kiranya untuk menemukan, apakah karyawan memiliki kepuasan atau tidak terhadap beberapa aspek pekerjaan atau masalah pribadi yang tidak berpengaruh langsung dengan pekerjaannya. Kepuasaan kerja juga tidak terlepas dari kompensasi yang diberikan oleh perusahaan, yaitu penghargaan sebagai budaya dan upaya dalam meningkatkan kualitas kerja (Hasibuan:2006).

Dalam (Sedarmayanti:2009) mengemukakan, bahwa kepuasan kerja adalah suatu keadaan emosi yang menyenangkan atau positif sebagai akibat dari pengalaman atau penilaian seseorang terhadap pekerjaannya. Menurut (Sedarmayanti: 2009) mengemukakan, bahwa kepuasaan kerja muncul akibat persepsi orang tentang cara-cara untuk melakukan pekerjaan dengan sebaiknya dan dapat memberi-kan suatu yang berarti kepada dirinya. Berdasarkan kedua pengertian ini dapat diartikan, bahwa kepuasan kerja pada diri seseorang muncul akibat pengaruh emosi yang menyenangkan atau positif berdasarkan pengalaman atau penilaiannya terhadap pekerjaan atau persepsinya tentang cara-cara utuk melakukan pekerjaan dengan sebaiknya dan mendatangkan keuntungan kepada dirinya. Secara umum kepuasan kerja mengacu kepada sikap individu terhadap pekerjaannya. Seseorang dengan tingkat kepuasan kerja tinggi mempunyai dan menyimpan sikap-sikap positif terhadap pekerjaanya, sedangkan orang yang tidak puas 
dengan pekerjaannya mempunyai dan menyimpan sikap-sikap negatif terhadap pekerjaannya (Umar, 2009:12).

Sementara (Sutano: 2007) mengemukakan, bahwa kepuasan kerja adalah cara pekerja merasakan kepuasan tentang pekerjaannya. Kepuasan kerja merupakan salah satu faktor penting yang mempengaruhi kepuasan hidup, karena sebagian besar waktu manusia dihabiskan di tempat kerja.

Kondisi menyenangkan atau secara emosional positif yang berasal dari penilaian seseorang atas pekerjaannya atau pengalaman kerjanya (Widodo: 2007). Suatu perasaan positif tentang pekerjaan seseorang yang merupakan hasil dari sebuah evaluasi karakteristiknya (Robbins \& Judge, 2008:107). Keadaan emosional yang menyenangkan atau tidak menyenangkan bagaimana para karyawan memandang pekerjaan mereka. Kepuasan kerja mencerminkan perasaan seseorang terhadap pekerjaannya (Handoko, 2008:193).

Berdasarkan pengertian di atas, kepuasan kerja mengacu kepada sikap individu terhadap pekerjaannya dan tingkat kepuasan kerja tinggi dapat lebih tinggi dapat memunculkan sikap yang lebih positif terhadap pekerjaanya, sebaliknya untuk tingkat kepuasan kerja yang lebih rendah dapat memunculkan sikap yang lebih negatif terhadap pekerjaan seseorang.

\section{Pengertian Motivasi}

Motivasi berasal dari kata movere yang berarti dorongan atau menggerakkan. Motivasi (motivation) dalam manajemen hanya ditujukan pada sumber daya manusia umumnya dan bawahan khususnya. Motivasi mempersoalkan bagaimana caranya mengarahkan daya dan potensi bawahan, agar mau bekerja sama secara produktif berhasil mencapai dan mewujudkan tujuan yang telah ditentukan.

Menurut (Hasibuan:2006) "Motivasi adalah pemberian daya penggerak yang menciptakan kegairahan kerja seseorang agar mereka mau bekerja sama, bekerja efektif dan terintegrasi dengan segala daya upayanya untuk mencapai kepuasan”. Menurut (Mangkunegara:2007). "Motivasi adalah kondisi yang menggerakan pegawai agar mampu mencapai tujuan dari motifnya".

Pada dasarnya motivasi itu hanya dua, yaitu untuk meraih kenikmatan atau menghindari dari rasa sakit atau kesulitan. Uang bisa menjadi motivasi kenikmatan maupun motivasi menghindari rasa sakit. Jika kita memikirkan uang supaya kita tidak 
hidup sengsara, maka disini alasan seseorang mencari uang untuk menghindari rasa sakit. Sebaliknya ada orang yang mengejar uang karena ingin menikmati hidup, maka uang sebagai alasan seseorang untuk meraih kenikmatan.

Dapat disimpulkan bahwa motivasi adalah suatu alasan atau dorongan yang bisa berupa kata-kata, motivation training, keyakinan dari dalam diri sendiri, pengaturan mindset, dan atau keadaan yang mendesak untuk dapat melakukan atau menghasilkan sesuatu, dan untuk memperoleh semangat untuk tetap terus bekerja. Dalam mewujudkan alasan untuk beraksi (motivasi), maka diperlukan stimulus (pendorong), stimulus (pendorong) itu sendiri ada dua macam, yaitu:

a. High Class yang berupa tarikan (pull).

b. Low Class yang berupa dorongan (push).

Jika kedua-duanya digabungkan, maka akan diperoleh suatu energi yang besar dan akan membangkitkan rasa semangat dalam diri seseorang, sebagai contoh: sebuah mobil yang mogok, jika didorong saja hanya akan bergerak lambat. Lain halnya jika ditambah dengan tarikan. Mobil itu akan terasa lebih ringan dan bergeraknya akan lebih cepat.

Begitu juga dengan diri manusia, manusia akan memiliki semangat juang yang tinggi jika mendapat dorongan dan kesadaran dari dalam dirinya sendiri. Tetapi semangat juang itu akan bertambah tinggi jika mendapat tarikan dari luar, seperti dorongan semangat dari keluarga, teman, atau yang lainnya. Ada beberapa level (tingkatan) dalam motivasi, yaitu:

a. Level paling rendah, level Spirit. Yaitu menghadiri AMT (Achievement Motivation Training). Kenapa level ini dikatakan paling rendah, karena pembakaran semangat dan motivasi di level ini hanya akan mempengaruhi peserta saat duduk dan menyimak motivasi yang diberikan oleh trainer (pemberi motivasi), setelah itu pengaruhnya tidak akan sekuat dan berpengaruh saat disampaikan oleh trainer;

b. Level Mindset. Pengaturan pada pikiran. Ini dilakukan oleh diri sendiri untuk menciptakan semangat dan motivasi untuk diri sendiri. Level ini lebih tinggi daripada sebelumnya, karena pada level ini kita sudah mampu mengatur apa-apa saja yang menjadi bahan bakar semangat dan alasan untuk melakukan sesuatu;

c. Level Skill dan Job. Kemampuan dan pekerjaan. Saat kita sudah mengetahui apa yang mampu kita lakukan dan pengaplikasiannya dalam pekerjaan, maka kita akan secara otomatis mendapat semangat dan alasan untuk menghasilkan yang terbaik dalam sasaran kita (job); 
d. Level yang tertinggi adalah Level Power (Energi). Kenapa disebut level tertinggi, karena pada level ini, seseorang yang telah mengatur mindset-nya, mampu melaksanakan job (pekerjaan) dengan baik, menjadi energi untuk yang lainnya. Artinya, disaat energinya habis, tahu kapan dan bagaimana seharusnya mengisi ulang energinya. Sedangkan disaat energinya sudah terisi penuh, maka ia mampu menyalurkan energi untuk orang lain.

\section{Peningkatan Produktivitas Pegawai}

Menurut (Indrsari, Methiana. 2009) Produktivitas kerja adalah kemampuan karyawan dalam berproduksi dibandingkan dengan input yang digunakan, seorang karyawan dapt dikatakan produktif apabila mampu menghasilkan barang atau jasa sesuai dengan diharapkan dalam waktu yang singkat atau tepat. Di dalam mencapai produktivitas yang tinggi suatu perusahaan dalam proses produksi, selain bahan baku dan tenaga kerja yang harus ada juga didukung oleh dua faktor sebagai berikut: kepuasan kerja dan motivasi.

Dengan karyawan yang memenuhi dua faktor vital dalam peningkatan produktivitas dalam bekerja, dapat menghasilkan karyawan yang berkualitas, efektif dan efisien. Dengan adanya keterlibatan karyawan, dapat meningkatkan komitmen dan semangat kerja, keterlibatan juga menjadi dasar pengendalian kualitas kerja dari karyawan di industri penerbangan. Sehingga organisasi dapat menghasilkan ide produk baru maupun metode - metode operasi yang lebih baik. Peningkatan produktivitas kerja pun berjalan dengan baik sehingga kualitas suatu perusahaan akan maju sesuai goal untuk merajai industri penerbangan di tanah air.

Peranan karyawan menurut (Mangkunegara:2007) bagi sebuah perusahan berupa keterlibatan mereka dalam sebuah perencanaan, sistem, proses dan tujuan yang ingin dicapai oleh perusahaan. Berbicara mengenai peranan tenaga kerja, harus dibedakan antara mereka yang memiliki pekerjaan dan mereka yang bekerja, dalam empat tingkatan (quadrant) yaitu self employed, employe, pebisnis dan investor. Karyawan adalah mereka yang bekerja pada orang lain dengan menjual jasa mereka; waktu, tenaga dan pikiran untuk perusahan dan mendapat kompensasi dari perusahan tersebut. Namun berbicara mengenai tenaga kerja ini masih umum, karena ada yang tidak bekerja, yang bekerja (pada orang lain/negara/swasta) dan mereka yang bekerja sendiri. 
Sumber daya manusia bukan hanya sebagai alat produksi tetapi juga sebagai penggerak dan penentu berlangsungnya proses produksi dan segala aktivitas organisasi (Mangkunegara:2007)

Produktivitas menurut (Sedarmayanti:2009) adalah ukuran sampai sejauh mana sebuah kegiatan mampu mencapai target kuantitas dan kualitas yang telah ditetapkan .Untuk itu sudah selayaknya pemilik lembaga baik swasta maupun pemerintah memberikan sebuah motivasi bagi karyawannya supaya menghasilkan produktivitas yang tinggi. Oleh karena itu suatu lembaga atau organisasi memberikan semacam perhatian yang khusus pada karyawannya untuk meningkatkan kemajuan dan kemampuan tenaga kerja serta kesejahteraan karyawan.

Produktivitas merupakan salah satu komponen yang harus dimiliki oleh suatu lembaga atau perusahaan apabila ingin mencapai tujuan yang telah ditetapkan. Dalam kegiatannya lembaga atau perusahaan harus mampu meningkatkan produktivitas dari waktu ke waktu, karena ini menyangkut terhadap kinerja lembaga tersebut. Aspek sumber daya manusia di dalam perusahaan atau lembaga memegang peranan penting, yaitu sebagai salah satu tolak ukur tingkat produktivitas kerja karyawan, dengan pengertian apabila tingkat kualitas sumber daya manusia di dalam sebuah perusahaan itu tinggi atau baik maka tingkat produktivitas kerja karyawan di lembaga tersebut lebih mudah meningkat, begitu pula sebaliknya apabila tingkat kualitas dari sumber daya manusia itu rendah atau kurang maka tingkat produktivitas kerja karyawan tersebut akan sulit untuk meningkat. Oleh karena itu bagi setiap lembaga yang ingin sukses dalam usahanya, diharuskan untuk lebih meningkatkan perhatiannya terhadap aspek sumber daya manusia yang dimiliki, dengan tujuan agar harapan serta tujuan dapat tercapai. Dalam usaha meningkatkan produktivitas kerja karyawan, tidak hanya mengandalkan segi kualitas produk yang dihasilkan, melainkan perusahaan atau lembaga juga perlu memperhatikan faktor-faktor yang mempengaruhi produktivitas kerja karyawan, seperti pengaruh kepuasan gaji/upah, kondisi kerja dan program pelayanan bagi karyawan. Dengan memperhatikan factor faktor yang dapat mempengaruhi tingkat produktivitas kerja karyawan, maka lembaga dapat lebih mengetahui serta memahami kebutuhan dan keinginan para karyawannya sehingga para karyawan bisa merasa lebih puas ataupun merasa lebih diperhatikan serta dapat melaksanakan kegiatan kerjanya secara optimal. 


\section{METODE PENELITIAN}

Metode penelitian bertujuan untuk mengukur pengaruh variabel Kepuasan Kerja dan Motivasi Terhadap Peningkatan Produktivitas Pegawai di PT. Glory Anugrah Tour, baik secara parsial dan simultan. Dalam penelitian ini akan digunakan analisis statistik untuk uji instrumen dan data dengan menggunakan program SPSS 16.

\section{Analisis dan Pembahasan}

\section{Uji Validitas Data}

Uji validitas data dengan melakukan korelasi antar skor butir pertanyaan/pernyataan dengan skor total variabel dengan hipotesis yang diajukan :

Ho $=$ skor pertanyaan/pernyataan berkorelasi positif dengan total skor variable $\mathrm{Ha}=$ skor pertanyaan/pernyataan tidak berkorelasi positif dengan total skor variabel.

Pada variabel kepuasan kerja jumlah sampel $(n)=60$ dan besarnya $\mathrm{df}=60-2=58$ dan alpha $(\alpha)=0,05$ didapat $r$ tabel $=0,266$.

\section{Keputusan :}

Jika $r_{\text {hitung }}$ positif dan $r_{\text {hitung }}>r_{\text {tabel, }}$, maka Ho diterima, butir tersebut valid.

Jika $\mathrm{r}_{\text {hitung }}$ negatif atau $\mathrm{r}_{\text {hitung }}<\mathrm{r}_{\text {tabel, }}$, maka Ho ditolak, butir tersebut tidak valid.

a. Uji Validitas Kepuasan Kerja ( $\left.\mathbf{X}_{\mathbf{1}}\right)$ Hasil uji validitas dengan mempergunakan sebanyak 60 responden, dimana menunjukkan bahwa data yang diperoleh adalah valid, sehingga data yang diperoleh pada penelitian ini layak untuk diuji. Nilai koefisien korelasi tertinggi pada masing-masing item untuk variable kepuasan kerja (X) adalah 0,729 dan nilai terrendah adalah sebesar 0,161 (lihat Tabel-1)

Tabel-1. Total Statistics Kepuasan Kerja (X)

\begin{tabular}{|c|c|c|c|}
\hline Pertanyaan & rhitung & rtabel & Kesimpulan \\
\hline $\mathrm{X} 1.1$ & .443 & .266 & valid \\
\hline $\mathrm{X} 1.2$ & .536 & .266 & valid \\
\hline $\mathrm{X} 1.3$ & $\mathbf{. 1 6 1}$ & $\mathbf{. 2 6 6}$ & Tidak valid \\
\hline $\mathrm{X} 1.4$ & .424 & .266 & valid \\
\hline $\mathrm{X} 1.5$ & .635 & .266 & valid \\
\hline $\mathrm{X} 1.6$ & .729 & .266 & valid \\
\hline $\mathrm{X} 1.7$ & .573 & .266 & valid \\
\hline $\mathrm{X} 1.8$ & .453 & .266 & valid \\
\hline $\mathrm{X} 1.9$ & .554 & .266 & valid \\
\hline $\mathrm{X} 1.10$ & .647 & .266 & valid \\
\hline
\end{tabular}

Sumber : Olahan SPSS, 2016 


\section{b. Uji Validitas Motivasi $\left(\mathbf{X}_{2}\right)$}

Hasil uji validitas dengan mempergunakan sebanyak 60 responden, dimana menunjukkan bahwa data yang diperoleh terdapat 1 butir memiliki nilai $r$ hitung $<\mathrm{r}_{\text {tabel }}$ tidak valid maka butir tersebut nilai dan skornya tidak akan dipergunakan untuk menjadi instrument penelitian (lihat Tabel-2), nilai koefisien korelasi tertinggi pada motivasi $\left(\mathrm{X}_{2}\right)$ sebesar 0,696 dan nilai terrendah sebesar 0,045.

Tabel-2. Item-Total Statistics Motivasi (X2)

\begin{tabular}{|c|c|c|c|}
\hline Pertanyaan & rhitung & rtabel & Kesimpulan \\
\hline $\mathrm{X} 2.1$ & $\mathbf{. 4 6 2}$ & .266 & valid \\
\hline $\mathrm{X} 2.2$ & $\mathbf{. 5 8 5}$ & .266 & valid \\
\hline $\mathrm{X} 2.3$ & $\mathbf{. . 0 4 5}$ & $\mathbf{. 2 6 6}$ & Tidak valid \\
\hline $\mathrm{X} 2.4$ & $\mathbf{. 6 1 4}$ & .266 & valid \\
\hline $\mathrm{X} 2.5$ & $\mathbf{. 4 4 2}$ & .266 & valid \\
\hline $\mathrm{X} 2.6$ & $\mathbf{. 6 9 6}$ & .266 & valid \\
\hline $\mathrm{X} 2.7$ & $\mathbf{. 2 4 8}$ & .266 & valid \\
\hline $\mathrm{X} 2.8$ & $\mathbf{. 5 1 8}$ & .266 & valid \\
\hline $\mathrm{X} 2.9$ & $\mathbf{. 6 2 0}$ & .266 & valid \\
\hline $\mathrm{X} 2.10$ & $\mathbf{. 2 9 4}$ & .266 & valid \\
\hline
\end{tabular}

\section{c. Uji Validitas Peningkatan Produktivitas Pegawai (Y)}

Hasil uji validitas dengan mempergunakan sebanyak 60 responden, dimana menunjukkan bahwa data yang diperoleh adalah valid (lihat Tabel-3), sehingga data yang diperoleh pada penelitian ini layak untuk diuji. Nilai koefisien korelasi tertinggi pada masing-masing item untuk koefisien korelasi tertinggi untuk peningkatan produktivitas pegawai sebesar 0,806 dan nilai terrendah sebesar 0,083 . Semua hasil uji validitas menunjukkan angka $\alpha<0,05$ sehingga dinyatakan valid.

Tabel-3. Total Statistic Peningkatan Produktivitas Pegawai (Y)

\begin{tabular}{|c|c|c|c|}
\hline Pertanyaan & rhitung & $\mathbf{r}_{\text {tabel }}$ & Kesimpulan \\
\hline$Y_{1}$ & .568 & .266 & valid \\
\hline$Y_{2}$ & .622 & .266 & valid \\
\hline$Y_{3}$ & $\mathbf{. 0 8 3}$ & $\mathbf{. 2 6 6}$ & Tidak valid \\
\hline$Y_{4}$ & .493 & .266 & valid \\
\hline$Y_{5}$ & .630 & .266 & valid \\
\hline$Y_{6}$ & .806 & .266 & valid \\
\hline$Y_{7}$ & .576 & .266 & valid \\
\hline$Y_{8}$ & .464 & .266 & valid \\
\hline$Y_{9}$ & .639 & .266 & valid \\
\hline$Y_{10}$ & .637 & .266 & valid \\
\hline
\end{tabular}

Sumber : Olahan SPSS, 2016 
2. Uji Reliabilitas data dilakukan untuk melihat instrument yang digunakan reliable dan data absah/valid dengan rumus Cronbach Alpha, berikut perhitungan uji reliability.

a. Uji Reliabilitas Variabel Kepuasan Kerja ( $\left.\mathbf{X}_{1}\right)$

Tabel- 4. Reliability Statistics

\begin{tabular}{|r|r|}
\hline Cronbach's Alpha & N of Items \\
\hline .838 & 10 \\
\hline
\end{tabular}

Reliability statistics di dapat koefisien reliabilitas (cronbach's alpha) sebesar 0,838 lebih besar dari 0,6 sehingga kesimpulan yang diambil adalah masing-masing item pertanyaan adalah reliabilitas

b. Uji Reliabilitas Variabel Motivasi $\left(\mathbf{X}_{2}\right)$

Tabel- 5. Reliability Statistics

\begin{tabular}{|r|r|}
\hline Cronbach's Alpha & N of Items \\
\hline .811 & 10 \\
\hline
\end{tabular}

Reliability statistics didapat koefisien reliabilitas (cronbach's alpha) sebesar 0,811 lebih besar dari 0,6 sehingga kesimpulan yang diambil adalah masing-masing item pertanyaan adalah reliabilitas (lihat Tabel-5).

c. Uji Reliabilitas Variabel Peningkatan Produktivitas (Y)

Reliability statistics didapat koefisien reliabilitas (cronbach's alpha) sebesar 0,854 lebih besar dari 0,6 sehingga kesimpulan yang diambil adalah masing-masing item pertanyaan adalah reliabilitas (lihat Tabel-6).

Tabel- 6. Reliability Statistics Peningkatan Produktivitas (Y)

\begin{tabular}{|r|l|}
\hline Cronbach's Alpha & N of Items \\
\hline .854 & 10 \\
\hline
\end{tabular}




\section{Uji Normalitas data}

Setelah dilakukan uji reliabilitas instrument dan dilakukan uji validitas data, maka perlu dilakukan uiji normalitas dengan melakukan uji chart adalah sebagai berikut :

Gambar-1. Histrogram peningkatan produktivitas pegawai

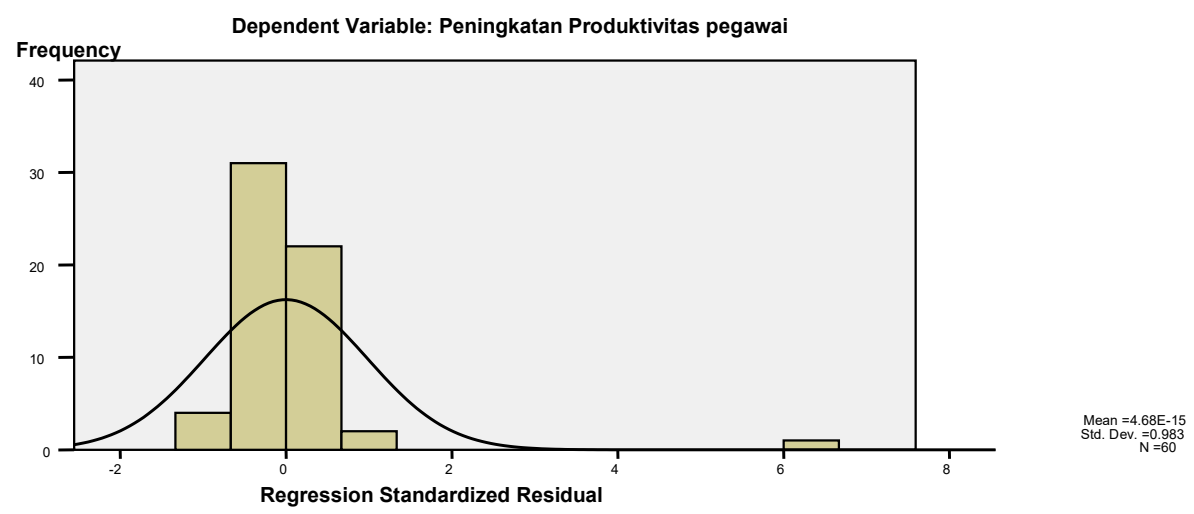

Dengan melihat tampilan grafik histogram memberikan pola distribusi yang mendekati normal. Sedangkan pada grafik normal plot terlihat titik-titik menyebar di sekitar garis diagonal, serta penyebarannya mengikuti arah garis diagonal, grafik tersebut menunjukan bahwa model regresi layak dipakai karena memenuhi asumsi normalitas.

\section{Analisa Koefisien Korelasi}

Untuk melihat gambaran serta korelasinya dengan program SPSS, maka didapat korelasi antara variabel bebas dengan variabel terikat secara parsial dan uraian hasil perhitungan sebagai berikut :

Tabel-7

\section{Correlations}

\begin{tabular}{|ll|c|c|}
\hline & & Kepuasan Kerja & Motivasi \\
\hline $\begin{array}{l}\text { Peningkatan } \\
\text { produktivitas pegawai }\end{array}$ & Pearson Correlation &. $\mathbf{9 1 7}(* *)$ &. $\mathbf{3 0 5}(*)$ \\
& Sig. (2-tailed) & .000 & .018 \\
& $\mathrm{~N}$ & 60 & 60 \\
\hline
\end{tabular}

** Correlation is significant at the 0.01 level (2-tailed).

* Correlation is significant at the 0.05 level (2-tailed).

Analisis: 
a. Besar pengaruh antara variabel kepuasan kerjad dan variabel peningkatan produktivitas pegawai yang dihitung dengan koefisien korelasi adalah 0,917 . Tanda ** berarti signifikan.

b. Besar hubungan antara variabel motivasi dengan variabel peningkatan produktivitas pegawai yang dihitung dengan koefisien korelasi adalah 0,305. Tanda * berarti signifikan.

c. Untuk melihat korelasi antara variabel bebas (X1 dan X2) dengan variabel terikat (Y), maka dengan melihat Tabel-7, dapat diintrepretasikan sebagai berikut berikut:

Untuk kepuasan kerja berpengaruh dengan variabel peningkatan produktivitas pegawai sangat kuat/korelasi sangat erat $(0,917>0,90)$. Variabel motivasi berpengaruh dengan variabel peningkatan produktivitas pegawai rendah /korelasi rendah $(0,305<0,40)$. Tingkat signifikan koefisien korelasi dua sisi dari output (diukur dari probabilitas) pada tabel korelasi (Correlations) menghasilkan angka 0.000 (terlihat pada tabel tanda Sig) maka korelasi variabel kepuasan kerja dan variabel motivasi dengan variabel peningkatan produktivitas pegawai signifikan karena probabilitas di bawah 0,05 .

\section{Regresi Linear Berganda}

Untuk dapat menggambarkan persamaan regresi dan melihat pengaruh variable bebas terhadap variable terikat, maka dilakukan proses perhitungan dengan program SPPS sebagai berikut :

Tabel-8. Coefficients(a)

\begin{tabular}{|ll|c|}
\hline \multicolumn{1}{|c|}{ MODEL } & B \\
\hline $1 \quad$ (Constant) & $\mathbf{. 2 1 3}$ \\
& Kepuasan Kerja & $\mathbf{. 8 7 2}$ \\
& Motivasi & $\mathbf{. 0 9 1}$ \\
\hline
\end{tabular}

a Dependent Variable: peningkatan produktivitas pegawai

Tabel selanjutnya menggambarkan persamaan regresi adalah sebagai berikut :

$$
\mathrm{Y}=\mathbf{0 , 2 1 3}+\mathbf{0 , 8 7 2} \mathrm{X1}+\mathbf{0 , 0 9 1} \mathrm{X} 2
$$

Kostanta sebesar 0,213 menyatakan bahwa jika tidak ada variabel Kepuasan kerja dan variabel motivasi, maka variabel peningkatan produktivitas pegawai adalah bernilai 0,213 . 
Koefisien regresi X1 sebesar 0,872 menyatakan bahwa setiap penambahan 1 satuan nilai variabel kepuasan kerja dan variabel lainnya tetap, maka akan menambah $(+)$ nilai variabel peningkatan produktivitas pegawai sebesar 0,872 satuan atau sebaliknya.

- Koefisien regresi X2 sebesar 0,091 menyatakan bahwa setiap penambahan 1 satuan nilai variabel motivasidan variabel lainnya tetap, maka akan menambah $(+)$ nilai variabel peningkatan produktivitas pegawai sebesar 0,091 satuan atau sebaliknya.

\section{Uji t, uji f, Determinasi}

\section{a. Uji t}

Untuk mengetahui kebenaran dari perhitungan korelasi, maka dilakukan pengujian hipopenelitian. Perumusan hipopenelitian yang akan diuji diberi simbol Ho, sedangkan hipopenelitian alternatif diberikan simbol Ha.

Tabel-9. Model Summary(b)

\begin{tabular}{|c|c|}
\hline Model & R Square \\
\hline 1 & .851 \\
\hline
\end{tabular}

1) Tabel VARIABLES ENTERED menunjukan bahwa tidak ada variabel yang dikeluarkan (removed), atau dengan kata lain kedua variabel bebas dimasukan dalam perhitungan regresi.

2) Angka $R$ square adalah 0,851. Hal ini berarti $85,10 \%$ variabel peningkatan produktivitas pegawai dijelaskan/dipengaruhi oleh variabel kepuasan kerja dan motivasi. Sedangkan sisanya $(100 \%-85,10 \%=$ $14,90 \%$ ) dijelaskan oleh sebab-sebab yang lain.

\section{b. Uji F}

Untuk melihat sejauhmana pengaruh variabel bebas kepuasan kerja dan motivasi dengan variabel terikat peningkatan produktivitas pegawai, maka dilakukan analisa uji $\mathrm{F}$ dengan program SPSS dan untuk melihat pengaruh setiap variabel dalam analisa regresi berganda, maka dilakukan uji ANOVA, adalah sebagai berikut : 
Tabel-10. Anovab

\begin{tabular}{|c|c|c|c|c|c|c|}
\hline $\begin{array}{c}\text { Mode } \\
1\end{array}$ & & $\begin{array}{c}\text { Sum of } \\
\text { Squares }\end{array}$ & $\mathrm{df}$ & $\begin{array}{c}\text { Mea } \\
\text { n } \\
\text { Squa } \\
\text { re }\end{array}$ & $\mathrm{F}$ & Sig. \\
\hline 1 & $\begin{array}{l}\text { Regress } \\
\text { ion } \\
\text { Residua } \\
1 \\
\text { Total }\end{array}$ & $\begin{array}{c}9.345 \\
1.635 \\
10.980\end{array}$ & $\begin{array}{l}57 \\
59\end{array}$ & $\begin{array}{c}4.67 \\
2 \\
.029\end{array}$ & $\begin{array}{c}162.85 \\
5\end{array}$ & $\begin{array}{c}.000( \\
\text { a) }\end{array}$ \\
\hline
\end{tabular}

a. Predictors: (Constant), X2, X1

b. Dependent Variable: Y

\section{Analisa}

Dari uji Anova atau $\mathrm{F}$ test (lihat Tabel 25), didapat $\mathrm{F}$ hitung sebesar 162,855. Pengujian satu variabel bebas $\mathrm{X}$ terhadap variabel $\mathrm{Y}$ dilakukan dengan uji $\mathrm{F}$.

1) Menentukan $F$ tabel dan $F$ hitung.

$\mathrm{F}$ tabel

Tingkat signifikan 5\%

Degree of freedom (df) :

Dari output komputer pada tabel ANOVA dan kolom df, didapat :

Numerator $=2$

Denumerator $=57$

Maka $\mathrm{F}$ tabel untuk F $(0,05 ; 2 ; 57)$ didapat $3,17$.

F hitung

Dari output komputer, pada kolom $F$ didapat $\mathrm{F}$ hitung sebesar 162,855.

2) Dengan membanding $F$ tabel dan $F$ hitung.

$\mathrm{Ho}=$ Tidak ada pengaruh atau hubungan antara variabel $\mathrm{X}$ dengan Variabel $\mathrm{Y}$

$\mathrm{Ha}=$ Ada pengaruh atau hubungan antara variabel $\mathrm{X}$ dengan Variab $\mathrm{Y}$

Jika $\mathrm{F}$ hitung $>\mathrm{F}$ tabel, maka Ho ditolak

Jika $\mathrm{F}$ hitung $<\mathrm{F}$ tabel, maka Ho diterima

Dengan membanding $\mathrm{F}$ tabel dan $\mathrm{F}$ hitung :

Terlihat $\mathrm{F}$ hitung $(162,855)$ lebih besar dari $\mathrm{F}$ tabel $(3,20)$, maka Ho ditolak. Berarti variabel kepuasan kerja dan motivasi secara bersama-sama berpengaruh dengan variabel peningkatan produktivitas pegawai dan signifikan oleh karena probabilitas 
$(0,000)$ jauh lebih kecil dari 0,05. Maka model regresi dapat dipakai untuk memprediksi variabel peningkatan produktivitas pegawai.

\section{KESIMPULAN DAN SARAN}

Berdasarkan analisis dan pembahasan, maka dapat ditarik kesimpulan dalam penelitian sebagai berikut.

\section{Kesimpulan}

a. Kepuasan kerja menunjukkan adanya pengaruh yang positif dan signifikan antara motivasi, berpengaruh antara variabel kepuasan kerja dan variabel peningkatan produktivitas pegawai dihitung dengan koefisien korelasi adalah 0,917 dengan nilai signifikan sebesar 0,103 .

b. Motivasi dengan variabel peningkatan produktivitas pegawai yang dihitung dengan koefisien korelasi adalah 0,305 dengan nilai signifikan terdapat pengaruh yang positif.

c. Pengaruh kepuasan kerja dan motivasi dengan variabel peningkatan produktivitas pegawai sangat kuat/korelasi sangat erat $(0,917>0,305)$.

\section{Saran}

a. Produktifitas karyawan perlu ditingkatkan dengan pelatihan, rekreasi untuk menghilangkan kejenuhan karyawan dalam bekerja.

b. Kepuasan kerja karyawan tidak hanya dari gaji, tetapi juga suasana kerja antar pegawai, antar atasan dan suasana kantor, untuk itu keberadaan dan emosioanal antar karyawan harus di jaga.

c. Motivasi kerja karyawan harus ditingkatkan dengan memberikan reward atau penghargaan atau pujian agar motivasi untuk bekerja dapat meningkat

\section{E. DAFTAR PUSTAKA}

Amstrong, Michael, 2001.Human Resource Management, Vol. 2 New Delhi: Crest Publishing House.

-2003.Managing People: A Pratical Guide For Line Managers (Jakarta : Gramedia.

Hasibuan, Malayu S.P. 2006 . Manajemen Dasar, Pengertian, Masalah, Jakarta : Bina Aksara. 
Aviasi: Jurnal Ilmiah Kedirgantaraan

Volume 17 Number 2 (2020)

Indrsari, Methiana. 2009. Kepuasan Kerja dan Kinerja Karyawan. Jakarta: Indomedia Pustaka

Umar, Husein,1999.Riset Sumber Daya Manusia dalam Organisasi. Jakarta: Gramedia Pustaka Utama.

Mangkunegara.2007 , Sumber Daya Manusia Indonesia, Jakana: Gunung Agung

Sedarmayanti. 2009.Sumber Daya Manusia dan Keinovatifan Karyawan, Bandung: CV Mandar Maju. , 2009.Reformasi Administrasi Publik, Reformasi, dan Kepemimpinan Masa Depan, Bandung: PT Refika Aditama.

Sutano, 2007.Dasar-Dasar Kepemimpinan Administrasi, Yogyakarta Gajah Mada University Press.

Widodo. 2007.Learning Organization; Pirani Pemimpin Msioner Malang: Bayumedia. 